\begin{tabular}{ll} 
Article & UC UNIVERSITY COUNCIL For \\
& ea EDUCATIONAL ADMINISTRATION \\
\hline
\end{tabular}

\title{
A Network Perspective on Dropout Prevention in Two Cities
}

Educational Administration Quarterly 20I5, Vol. 5I(I) 27-57

(C) The Author(s) 2013

Reprints and permissions:

sagepub.com/journalsPermissions.nav DOI: $10.1177 / 0013161 \times 13511110$

eaq.sagepub.com

@SAGE

\section{Rebecca Wells', Elizabeth Gifford², Yu Bai², and Ashley Corra ${ }^{2}$}

\begin{abstract}
Purpose: This exploratory case study examines how school systems and other local organizations have been working within two major U.S. cities to improve high school graduation rates. Systematically assessing active interorganizational dropout prevention networks may reveal characteristics affecting communities' capacity to support school completion. Research Method: This study included the local affiliates within two U.S. cities of national partners in a dropout prevention initiative. A survey and follow-up interview probed for each organization's cooperation with the other local organizations. Social network analyses revealed how school superintendents' offices and other local agencies cooperated, as well as which organizations were most central within each city's dropout prevention network. Findings: School systems in both cities cooperated with the YMCA, Big Brothers Big Sisters, Boys and Girls Club, the mayor's office, United Way, and Chamber of Commerce. Among the most central organizations in broader dropout prevention-related networks were the YMCA, Communities in Schools, mayor's office, and the United Way. Implications for Research and Practice: An organizational network perspective can help school systems identify strategic opportunities to build local capacity for supporting youth. Working with key brokers may then offer a feasible way for schools to leverage local resources.
\end{abstract}

\footnotetext{
'Texas A\&M University, College Station, TX, USA

${ }^{2}$ Duke University, Durham, NC, USA

Corresponding Author:

Elizabeth Gifford, Center for Child \& Family Policy, Duke University, Box 90545, Durham, NC 27708-0264, USA.

Email: beth.gifford@duke.edu
} 


\section{Keywords}

dropout prevention, community capacity, social network analysis, interorganizational cooperation, intersectoral

\section{Introduction}

Despite a decade of improving graduation rates, a quarter of U.S. youth still do not graduate from high school (Matthews, 2012). For individuals, failure to complete high school is associated with unemployment, poverty, reliance on social assistance programs, incarceration, and poor health (Rouse, 2005; Rouse \& Kemple, 2009; Sum, IKhatiwada, McLaughlin, \& Palma, 2009). Regionally, metropolitan areas with higher proportions of high school dropouts have weaker economies (Swanson, 2009).

Many factors can reduce youths' chances of completing high school, including household moves, employment to support their families, pregnancy, and involvement with the justice system (Bowers, Sprott, \& Taff, 2013; Hammond, Linton, Smink, \& Drew, 2007; Hirschfield, 2009; Rumberger \& Larson, 1998). Skepticism about the value of a diploma can also lead youth to drop out (Abar, Abar, Lippold, Powers, \& Manning, 2012; Davis, Ajzen, Saunders, \& Williams, 2002). Both parental and child behavioral health problems as well may reduce the probability of completing high school (Farahati, Marcotte, \& Wilcox-Gök, 2003; Hammond et al., 2007).

Because so many nonacademic factors affect graduation, promising dropout prevention strategies often rely on resources beyond schools. For example, health and social services may reduce school absences caused by illness, pregnancy, and family dynamics, as well as address behavioral problems before they escalate (Freudenberg \& Ruglis, 2007). Mentors and advocates can help children overcome social isolation (Randolph \& Johnson, 2008; Tyler \& Lofstrom, 2009). One-on-one instruction by tutors at community organizations can help children keep up with peers (Lehr, Hansen, Sinclair, \& Christenson, 2003; Ritter, Barnett, Denny, \& Albin, 2009). Finally, community service offers young people meaningful contexts in which to serve others, and thereby better appreciate their value to society (Melchior \& Bailis, 2002; Scales, Blyth, Berkas, \& Kielsmeier, 2000).

Leaders within and beyond schools have been seeking to build systems that support academic success for all children. Despite the challenges of changing public bureaucracies with many stakeholders (Dynarski \& Gleason, 2002; Kahne, Brown, \& Quinn, 2001), some schools have restructured to increase relevance and thus student engagement. In addition, local community partners have been increasingly active in recent years. Some of these efforts, such as community organizing, have sought to change the ways schools function, 
including accepting parents and local organizations as equal partners (Mediratta, 2007). Other initiatives have not emphasized changing power dynamics but are still organized around public schools as hubs for a range of youth and community-oriented services (Smith \& Wohlstetter, 2001). Finally, another approach is mobilizing a range of community organizations to support children and youth, not necessarily through or at the schools themselves (Newell \& Akers, 2010).

The interdependencies of factors affecting children's academic progress (Randolph \& Johnson, 2008; Tyler \& Lofstrom, 2009) merit investigation of how schools and other organizations work together within communities to improve graduation rates. Measuring and contextualizing the structure of local dropout prevention efforts can inform better strategic investments of leadership time as well as other resources. The purpose of this exploratory case study was therefore to identify how school systems and other organizations have cooperated locally to promote school completion, and which local partners appear the most promising for future such initiatives.

\section{Theoretical Perspective: The Role of Organizational Networks in Dropout Prevention}

Community capacity to support children through high school completion requires the mobilization of not only human, physical, and financial capital but also social capital (Coleman, 1988). By social capital we refer to " $[t]$ he resources embedded in social relations and social structure which can be mobilized when an actor wishes to increase the likelihood of success in purposive action" (Lin, Cook, \& Burt, 2001, p. 24). Social capital is vital to improving high school graduation rates because children at risk of dropping out have complex needs that no one organization can fully address (Boje \& Whetten, 1981). Thus, just as skilled professionals and sufficient funds are necessary to support children at risk, so is their effective coordination.

Although most prior social network analyses in education have focused on interpersonal ties, such as those between parents and teachers and among school faculty and staff (Coburn \& Russell, 2008; Daly \& Finnigan, 2010), some have examined interorganizational cooperation (Song \& Miskel, 2005). Some local school improvement initiatives have secured resources from partners such as universities, education reform groups, and consultants (Smith \& Wohlstetter, 2001). Wohlstetter and Smith (2006) argue that all schools can learn from charter schools' collaborations with health and human service agencies, cultural organizations, and businesses. Other prominent school improvement initiatives have been structured as nonprofit 
"hubs" implemented by school "outlets" (Peurach \& Glazer, 2012). These studies illustrate both the diversity of interorganizational networks in education and their potential benefits, suggesting the utility of further explicating how schools and other organizations are collectively addressing dropout prevention in local communities.

Studies of other health and human services have suggested that understanding the nature of connections among local organizations can reveal both the current level of integration (Agranoff, 1991) and the capacity to undertake new initiatives (Foster-Fishman, Salem, Allen, \& Fahrbach, 2001). However, building and sustaining interorganizational cooperation requires substantial time investments by individuals whose many other competing priorities typically have more direct impact (Lawson, Claiborne, Hardiman, Austin, \& Surko, 2007). Hence, communities need focused guidance about how to build their capacity to support children's academic success.

A community's capacity to address children's interrelated needs may be related to organizations' ability to exchange information with each other, coordinate service provision, and share resources (Brown, Hawkins, Arthur, Briney, \& Fagan, 2011). Different types of resources can flow through these interactions. For instance, information flows through communication ties, and people flow through referral ties. Any two actors can exchange a range of different combinations of resources. Such dyadic exchanges between any two organizations are the building blocks of a network, aggregating to varying structures of resource flows and thus differing collective capacities for action. Paths between any two organizations within a broader network may be direct or mediated through other organizations. For example, the mayor's office may provide money to an intermediary who contracts with others to provide direct services to families. If a potential contractor and the intermediary do not communicate, then the contractor may be excluded from key events. Thus, an organization's position within the network for any given type of interaction affects how much of that resource the organization receives (Borgatti \& Ofern, 2010).

More important, the structures of health and human service networks may affect how well people's needs are met. More than 30 years ago, Boje and Whetten (1981) made the case that "when organizations providing one type of service refer clients to, get information about, and otherwise interact with organizations providing other types of services, the interests of multiple-need clients are served more effectively than if such interaction does not occur" (p. 346). Yet few prior studies have systematically measured multiple types of cooperation supporting children (Hite, Williams, \& Baugh, 2005). One of the current study's contributions is examining four different ways local organizations have worked together to address graduation rates. 
Perhaps most fundamentally, exchanging information can build common understanding of individual and collective child needs as well as support coordinated action (Provan \& Milward, 1995). Both formal and informal crossagency information sharing can expand each partner's awareness of children's needs and how best to work together to address them. For example, when homeless shelter staff communicate with school staff about how a family's housing situation is affecting a child, a plan may be jointly developed that addresses the child's needs and recalibrated as the situation changes (Miller, 2009). When staff at different agencies understand each other's goals and resources, as well as policy and regulatory constraints, they can also better capitalize on each other's resources (Lawson et al., 2007). At the community level, the business sector may become more supportive of investments in education when they have more appreciation of how those resources are used (Johansson, 2010). Some interventions for at-risk families entailing greater communication between agencies have improved service engagement and outcomes (Ryan, Marsh, Testa, \& Louderman, 2006). Research also suggests that local interorganizational partnerships are more effective when participants are able to focus on common goals (Fairnington, 2004). Communication between organizations may therefore indicate capacity both to serve children through current programs and to undertake new initiatives (Lawson et al., 2007; Maton, 2008).

Children at risk of academic failure often need a range of health and social services, which must address family circumstances as well as cultural norms. Ideally, agencies refer children and their families whenever other local organizations can better address some aspect of their needs (Levine \& White, 1961; Provan \& Milward, 1995). Staff members referring individuals to other organizations also have opportunities to build mutual trust and shared understanding of how to support children and their caregivers. Thus, a greater number of organizations referring to each other should indicate not only more current cooperation but also greater potential to implement new cooperative endeavors, especially those related to complex needs (Lawson et al., 2007; Levine \& White, 1961). Unsurprisingly, given that human service agencies are "people processing" organizations (Hasenfeld, 1972), referrals have been the most common measure of interagency coordination in human service networks (Bolland \& Wilson, 1994; Provan \& Huang, 2012).

Sharing resources across organizations also indicates greater community capacity because often some organizations are best equipped to lead a program, whereas others have additional necessary resources. These may include money, facilities (Hite et al., 2005), or other "in-kind" support (Lawson et al., 2007). Given the labor intensive nature of service provision, often the most important resource organizations can share is staff. Such exchanges can in 
turn improve the quality of communication between agencies that are addressing individual children's interrelated needs. Another increasingly common shared resource is space. For example, agencies in one youth development initiative used a common facility that also facilitated sharing of additional resources and mutual problem solving among staff. In-kind contributions helped sustain some of these programs after grant funding ended (Lawson et al., 2007). As new, small, entities with fewer restrictions than traditional schools, charter schools have sometimes extended relationships with community partnerships to include physical accommodations. For instance, the founders of one charter school asked a local museum to house them (Smith \& Wohlstetter, 2006). Such interorganizational resource exchanges should better meet the needs of individual children by expanding the range of supports available. In addition, efficiency gains in service provision may allow for broader programmatic improvements.

Finally, joint programs may improve an organization's supply of clients or capacity to serve them (Boje \& Whetten, 1981) and thus enhance system capacity (Provan \& Milward, 1995). Like less tightly coupled forms of exchange such as shared resources, joint programs among agencies with differing emphases can create a collective capacity to meet children's needs more holistically. For instance, full service schools provide health care and other services to reduce impediments to learning (Adelman \& Taylor, 1997). A Boys and Girls Club that started a charter school provided space, equipment, and business services (Smith \& Wohlstetter, 2006). In the resourceconstrained and high-stress environments that typify work with children at risk, joint programs can also improve peer mentoring and social support for front-line staff, and thus potentially their own well-being and retention.

Several dyadic social network measures can reveal capacity to support children's academic success. The first is multiplexity, or the number of different types of ties between any given pair of actors (Wasserman \& Faust, 1994). More multiplex ties - for example, both exchanging information and financial or other resources - indicate stronger connections and thus greater cooperative capacity (Provan \& Milward, 1995). A second measure of tie strength is reciprocity, or whether any given resource flows in one or both directions (Granovetter, 1973; Wasserman \& Faust, 1994). Although one-way flows may sometimes be appropriate, reciprocity generally makes relationships more robust (Bennett \& Thompson, 2011; Goldring \& Sims, 2005). Network theory implies that an organization with stronger dyadic ties is better positioned to achieve its goals. At the network level, the aggregation of such stronger ties should yield greater community capacity for action.

Other measures indicate how well a given organization is positioned to leverage resources from its broader network. For instance, range indicates 
the extent to which an organization's network spans institutional or social boundaries (Burt, 1992). Wider ranging networks may indicate greater capacity to combine complementary resources toward common goals. Finally, an organization's centrality within a network indicates its level of access to information and other resources (Freeman, Roeder, \& Mulholland, 1979), and hence potential capacity to mobilize network resources. Specifically, information brokers who span otherwise disconnected actors are structurally positioned to make new connections fostering the accomplishment of common goals (Burt, 1992, 2004).

Given their primary responsibility for education, the first focus in the current study was on how schools cooperated with local partners to improve graduation rates. The current study contributes to educational research by examining how two large public school systems worked with other local partners. Because of our interest in system-level capacity, we focused on each school superintendent's office. Thus, the study's first research question was the following:

Research Question 1: How are school systems working with local partners to improve high school graduation rates?

Based on prior network research, we considered more multiplex and reciprocal ties with any given other agency, greater intersectoral range, and higher centrality within local dropout prevention networks to indicate more social capital available to school systems for improving graduation rates.

In general, any given actor is unlikely to be aware of the network beyond its own set of ties (Cook, Emerson, \& Gillmore, 1983). The critical role other organizations play in supporting youth (Hirota, 2005) and the potential relevance of non-school-based dropout prevention efforts prompted our second research question, which was the following:

Research Question 2: How are other local organizations cooperating with each other to improve high school graduation rates?

Prior research suggests that the most central agencies within these networks would be best positioned to facilitate dropout prevention efforts (Boje \& Whetten, 1981; Friedkin \& Slater, 1994). However, no previous studies have examined the structure of dropout prevention-related cooperation among community agencies. By measuring how school systems and other local partners have supported academic success in two cities, the current study sought insights that might help leaders in other communities leverage opportunities to improve graduation rates. 


\section{Method}

\section{Context}

This case study was conducted as part of an evaluation of the America's Promise Alliance (the "Alliance") Grad Nation campaign, a national effort to ensure that all children graduate from high school ready for college, work, and life (Rumberger, 2011). Founded with Colin Powell as Chairman, the America's Promise Alliance grew out of a summit attended by 4 former presidents, 30 governors, 100 mayors, and 145 community delegations, and includes diverse partners focused on youth well-being (http://www.americaspromise.org/Aboutthe-Alliance/APA-History.aspx). One component of the Grad Nation campaign was a Featured Communities initiative seeking to increase local interorganizational cooperation. This began with leadership from 21 national Alliance partners who had local affiliates in many communities.

Twelve cities agreed to participate in the America's Promise Alliance Featured Communities initiative. The current study focuses on two of those cities chosen for additional data collection based on high participation in a 2008 online survey. During the 2008-2009 study period, both cities had become involved in the America's Promise Alliance, including participating in this initiative's national meeting. Each of these cities also hosted its own dropout prevention summit during this time and received $\$ 10,000$ for that summit from the America's Promise Alliance.

Both cities are among the 50 most populous metropolitan areas in the United States. In City A, the largest school district was represented in our study. City B has a single school district. City A's school system was generally stable during the study period. Like many urban districts, that in City B was undergoing major structural change. To protect the privacy of study participants, organizations with names not common across the United States are referred to by organization type and the city is not always specified in examples of dropout prevention activities. Data collection was approved by the institutional review board of the evaluator's university.

The network in each city was defined as local affiliates of the 21 national America's Promise Alliance partners present in that city in 2008, including school superintendents, a range of service providers, mayors, the United Way, and the Chamber of Commerce. In City A 19 local affiliates were present and in City B 16 were present. To include the most active dropout prevention partners of the original participants, members of the study team contacted any additional organization identified in the survey by representatives of two or more local America's Promise affiliates in that city to ask them to participate in the study (Laumann, Marsden, \& Prensky, 1992). This modified snowball process ensured that we did not omit any major participants in local 
dropout prevention-related cooperation, while also avoiding inclusion of any partners idiosyncratic to a single agency (Knoke \& Yang, 2007).

In City A, all 19 local affiliates of America's Promise national partners participated in the survey and 14 of the 19 were also interviewed. Neither of the two additional organizations identified by local affiliates as partners in dropout prevention responded to requests by the study team. Thus, the final survey response rate in City A was $90 \%$ for the online survey used as the basis for social network analyses (19 of the final sample of 21 ) and $67 \%$ for the interview (14 out of 21 ). In City B, no additional organizations were named by two or more of the 16 America's Promise affiliates. All 16 City B local affiliates participated in the online survey, for a $100 \%$ response rate. Of the $16,14(88 \%)$ were also interviewed. In both cities, representatives of all the most central organizations were interviewed.

\section{Data Collection Process}

Two stages of identification ensured that each local organization was represented by someone knowledgeable about its dropout prevention activities. First, the leader of each national organization participating in America's Promise Featured Communities initiative (e.g., the CEO of United Way of America) personally contacted the local affiliate in each city, asking them to participate in the initiative. America's Promise national staff then shared this contact information with members of the study team. Position titles of local study participants (e.g., CEO, Director of Operations, Chief Programs Officer) confirm that they oversaw youth-related programs.

In August 2008, the study team emailed each local affiliate representative, requesting participation in an online survey addressing their organization's dropout prevention activities. A member of the study team then interviewed representatives of local organizations over the phone between March and July 2009, whenever possible interviewing the same individual who had completed the online survey ( $93 \%$ in City A and $86 \%$ in City B). During the phone interview, after collecting background information on the individual, the interviewer asked the respondent to characterize his or her organization's overall range of 2008 dropout prevention activities and verify and explain cooperation with other organizations reported in the 2008 online survey as well as address other topics related to the broader program evaluation.

When interview descriptions of interagency ties contradicted previous online survey responses, the corrections were incorporated into the data prior to analyses. We privileged interview responses over survey responses because the interview occurred several months later, allowing participants to provide updated information, and because the interview was a more interactive 
format that gave participants a second chance to hear how we defined each type of tie and ask clarifying questions. Often, with prompting from the interviewer, study participants identified additional ties (a total of 121 in City A and 123 in City B out of a total of approximately 1,600 potential ties in each city). For instance, the Chamber of Commerce representative realized during an interview that they did in fact share information with the mayor's office. In far fewer instances, when the interviewer reminded participants of the study's operational definition of a given type of tie, the individual concluded that a previous report had either been erroneous or was no longer extant (e.g., Catholic Charities reporting that they no longer provided joint service with 4-H); this happened a total of 15 times in City A and 11 times in City B.

All interviews were professionally transcribed and checked by a member of the study team for accuracy. Finally, to understand the context of each city's dropout prevention network, members of the study team attended a dropout prevention summit in each city and read minutes from meetings among network participants held during 2008 and 2009 (four meetings in City A and three meetings in City B).

\section{Measures}

The online survey for each city included a roster of all the local Alliance affiliates in that city, from which each respondent was asked to check whether his or her organization had worked with each other organization "directly and locally in the past 12 months" on dropout prevention. When respondents indicated that they had worked with another local organization, they were then asked four separate yes/no questions about whether their organization had (a) provided the other organization with information either for an individual or as part of a broader dropout prevention effort, (b) referred individuals, (c) contributed financial or in-kind resources, and/or (d) provided services jointly with the organization. In addition, respondents were asked to write in the names of any additional local partners with whom their agency worked in each particular way; this was used as the basis for identifying additional local organizations to add to each city's network.

\section{Organizational Network Analyses}

Each information, referral, and resource tie was coded as present $(=1)$ when the representative of one organization reported cooperating in that way with another organization either in the online survey or during the phone interview review of the online responses (e.g., "We provided [name of organization] with information either for an individual or as part of a broader effort"). 
Information, referral, and resource ties were often one-way, for example, one organization reported providing information to a second organization, but the latter organization did not report providing information to the first (Levine \& White, 1961). Joint services were coded as present when reported by either organization because (a) even knowledgeable individuals may not know about all their organization's activities; (b) respondents were told that no published accounts would identify their city, and hence there was no incentive to overreport ties; (c) our interviewer had prompted respondents to reconsider all the interorganizational activities they had reported in the survey, thus reducing the possibility of erroneous reports of ties; and (d) individuals in different organizations may have defined the boundaries of dropout prevention differently. By including activities reported by either partner, we favored a more expansive definition of such activities, which fit the body of research showing that many direct and indirect factors affect high school completion (Hammond et al., 2007).

One organization - the League of United Latin American Citizens (LULAC) in City A - was surveyed and interviewed, but had been omitted from the list provided to other local affiliates because they joined America's Promise after the initial survey was sent. To retain LULAC in the analyses, we coded any ties that individual reported as confirmed. The respondent's tendency to characterize ties in reciprocal terms increased our confidence that the results did not overstate ties (e.g., "Yes, we do information sharing").

One author repeatedly read all interviews, meeting minutes from each city's regular dropout prevention network meetings, and study team member dropout prevention summit observational notes; applied descriptive codes for each type of tie to these study documents (e.g., informational; Miles \& Huberman, 1994) using NVivo 8 qualitative software; compiled examples of study participants' dropout prevention activities; developed descriptive profiles of cooperation within each city; used both these coded text segments and social network data to characterize patterns of cooperation within each city as well as similarities and differences across the two cities; and identified interpretive themes that emerged across multiple documents within and across the two sites. For instance, the first code to reveal the impact of City B's school system crisis on dropout prevention cooperation was information exchange, as network participants commented on their difficulty engaging school leaders. Perhaps because information exchange is a precondition to other types of cooperation, this code also revealed the communication benefits of City B's relatively small size in comparison to City A. Conversely, comparing coded text segments across cities for referrals revealed similar reports of referring children to other organizations providing complementary services as well as the role that the United Way in each city played in facilitating referrals to 
appropriate service providers. Boys and Girls Clubs in both cities also emerged as offering joint programs at their sites with other youth-serving agencies, as documented in prior research (Smith \& Wohlstetter, 2006). During this process, this author met repeatedly with another author who was deeply familiar with the study sites to review, refine, and validate interpretations.

Network analyses were conducted in Pajek software (de Nooy, Mrvar, \& Batagelj, 2005). The first set of analyses examined each school superintendent office's dropout prevention ties with local partners. These were egocentric analyses in that they were restricted to how a single actor related to other actors in the system (Wasserman \& Faust, 1994). Multiplexity was measured as the number of different types of ties to and/or from the superintendent and each other organization in the network, ranging from zero to two for each directed tie and zero or one for joint programs, which were inherently reciprocal. To assess reciprocity, we determined whether the superintendent's office (a) sent any resources to each other local organization and (b) received any type of resource (not necessarily the same type) from that organization (represented in Figure 1 as a two-headed arrow). To assess each school system's range of local prevention partners across sectors, we categorized local agencies as community organizations (e.g., the YMCA); professional associations (e.g., the American Academy of Pediatrics); entities focused on advocacy for African Americans and Latinos (the Urban League and League of United Latin American Citizens); government (the mayor's office); brokers between donors and community organizations (the United Way and Corporation for National and Community Service); and the business sector (the Chamber of Commerce and State Farm).

The second set of analyses entailed the whole network in that they included all organizations in each city's dropout prevention network. To assess the level of cooperation in each city, we calculated the mean number of partners that respondents in each network reported for each type of activity. We then used the mean total number of ties in each city to reflect the overall level of interorganizational cooperation around dropout prevention in that network (i.e., a measure of network density useful for comparing across networks of different sizes (Anderson, Butts, \& Carley, 1999).

We measured how central each organization was within each city's dropout prevention network in three ways (Wasserman \& Faust, 1994). Out-degree (reaching out) centrality was measured through the number of other organizations each organization reported cooperating with on at least one dropout prevention activity. In-degree (receiving) centrality was measured as the number of other organizations that reported each organization as a dropout prevention partner (de Nooy et al., 2005). Finally, potential communication brokers within each city's dropout prevention network were identified from instances in which 


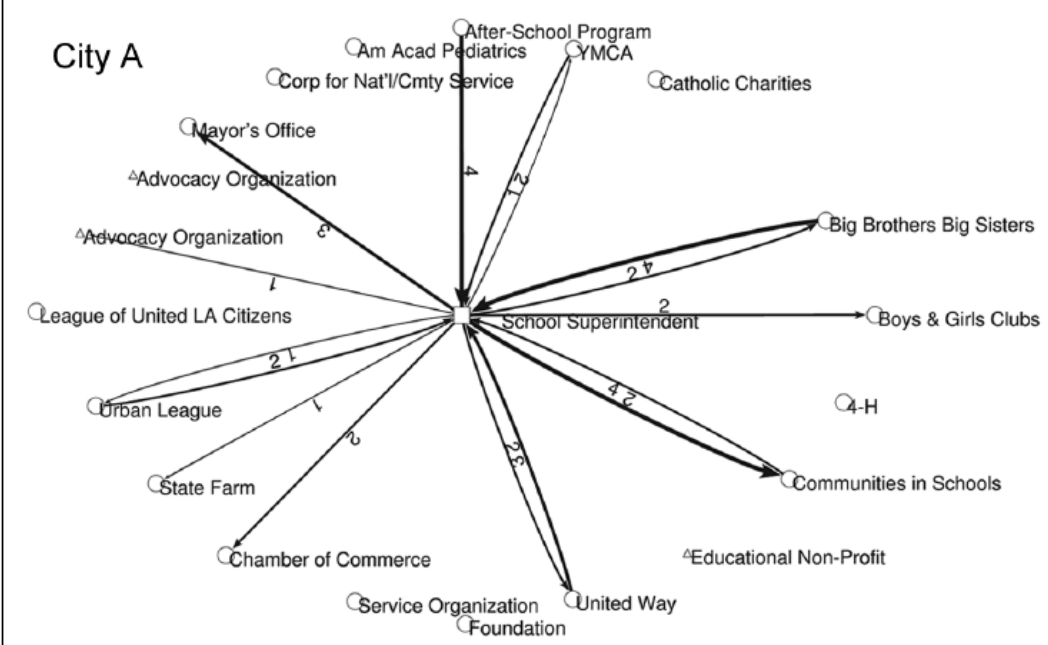

Five out of 11 of the City A superintendent's connections (45\%) were reciprocal.

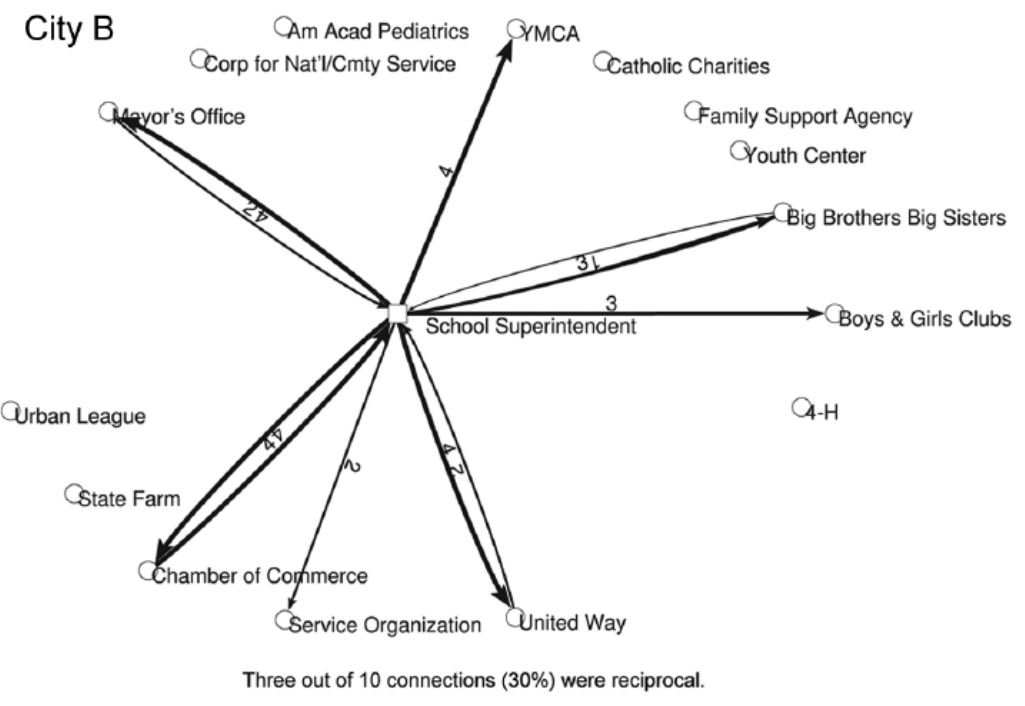

Figure I. Superintendent dropout prevention ties with local partners in City A and City B.

one organization reported sharing information with a second and the second organization reported sharing information with a third, but the first organization did not report sharing information directly with the third organization. In 
Table I. Profiles of Study Cities' Populations.

\begin{tabular}{|c|c|c|}
\hline $\begin{array}{l}\text { City Statistics (Reported in Ranges to Protect City } \\
\text { Identities) }\end{array}$ & City A & City B \\
\hline Metropolitan Statistical Area population ${ }^{\mathrm{a}}$ & Over 3 million & Over I million \\
\hline $\begin{array}{l}\text { Graduation rate in urban areas }{ }^{b} \text { (national average } \\
\text { in urban areas }=53 \% \text {; overall } 71 \% \text { ) }\end{array}$ & $55 \%$ to $65 \%$ & $40 \%$ to $50 \%$ \\
\hline$\%$ children living in poverty ${ }^{a}$ & $20 \%$ to $25 \%$ & $15 \%$ to $20 \%$ \\
\hline$\%$ children African American ${ }^{a}$ & $15 \%$ to $20 \%$ & $15 \%$ to $20 \%$ \\
\hline$\%$ children Latino ${ }^{\mathrm{a}}$ & Over $30 \%$ & Under $20 \%$ \\
\hline
\end{tabular}

aU.S. Census Bureau (2010). 'bSwanson (2009).

such an instance, the second organization could share information between the other two (Scott, 2000). Each organization's information betweenness centrality score was the proportion of the shortest paths of information ties between other organizations that included that organization - that is, how much that organization mediated communication between other network members (de Nooy et al., 2005). Given the second research question's whole network focus, we used these measures to identify which agencies were most central (and thus potentially influential) within each city.

\section{Results}

\section{Descriptive Network Profiles}

The two cities included in the current study were generally comparable to the other 10 cities participating in the America's Promise Featured Communities initiative at that time and more generally representative of medium-sized U.S. cities in their size and demographics. Their average population was approximately three million (Table 1), comparable to those of all but the largest two other Featured Communities. Cities A and B also had very similar graduation and poverty rates to those of the other cities, although fewer African American children and more who were Latino. The high school graduation rates in urban areas for all 10 cities where these statistics were available were 15 to 30 percentage points below the national average of $71 \%$ (Swanson, 2009).

Table 2 describes the two study cities' dropout prevention networks, which are also depicted in Figure 2. Reflecting America's Promise national partners, the majority of each local network's members were community organizations, 
Table 2. Dropout Prevention Networks.

\begin{tabular}{lcc}
\hline & \multicolumn{2}{c}{ Study Networks } \\
\cline { 2 - 3 } & City A & City B \\
\hline Number of organizations & 21 & 16 \\
Number of survey participants & $19(90 \%)$ & $16(100 \%)$ \\
Number interviewed & $14(67 \%)$ & $14(88 \%)$ \\
Organizational membership composition & & \\
Education & $2(10 \%)$ & $1(6 \%)$ \\
Community organization & $13(62 \%)$ & $10(63 \%)$ \\
Professional association & $2(10 \%)$ & $1(6 \%)$ \\
$\quad$ Government & $2(10 \%)$ & $2(13 \%)$ \\
Business & $2(10 \%)$ & $2(13 \%)$ \\
Attributes of organizational representatives & \\
\# years at organization & & \\
\# years in community & 10.6 & 12.4 \\
Information sharing & 15.3 & 15.2 \\
Referring individuals & 3.8 & 4.9 \\
Resource contributions & 2.0 & 2.9 \\
Joint services & 1.7 & 2.8 \\
\% ties reciprocated & 1.9 & 2.5 \\
Number of organizations each organization reported & $36 \%$ & $55 \%$ \\
cooperating with in at least one of the above ways & 4.8 & 6.7 \\
\hline
\end{tabular}

aln two organizations, two individuals were interviewed to address the range of dropout prevention programs offered.

such as 4-H, Big Brothers Big Sisters, Boys \& Girls Club, and the YMCA. Government, business, and professional associations each constituted less than $15 \%$ of each network. Individuals representing organizations within the two study networks tended to have spent over a decade at their organization (mean organizational tenure $=10.6$ years in City A and 12.4 years in City B) as well as in their community (mean $=15.3$ years in City A and 15.2 years in City B). These statistics are in keeping with position titles suggesting substantial knowledge about organizations' activities. The average numbers of cooperative ties reported in Cities A and B (combined mean of 5.8) than in the other 10 America's Promise cities (2.3), in addition to their high rates of participation in the online survey, suggest that Cities A and B had unusually active dropout prevention networks. These cities were thus considered exemplary cases from which other communities might learn (Yin, 2009). 


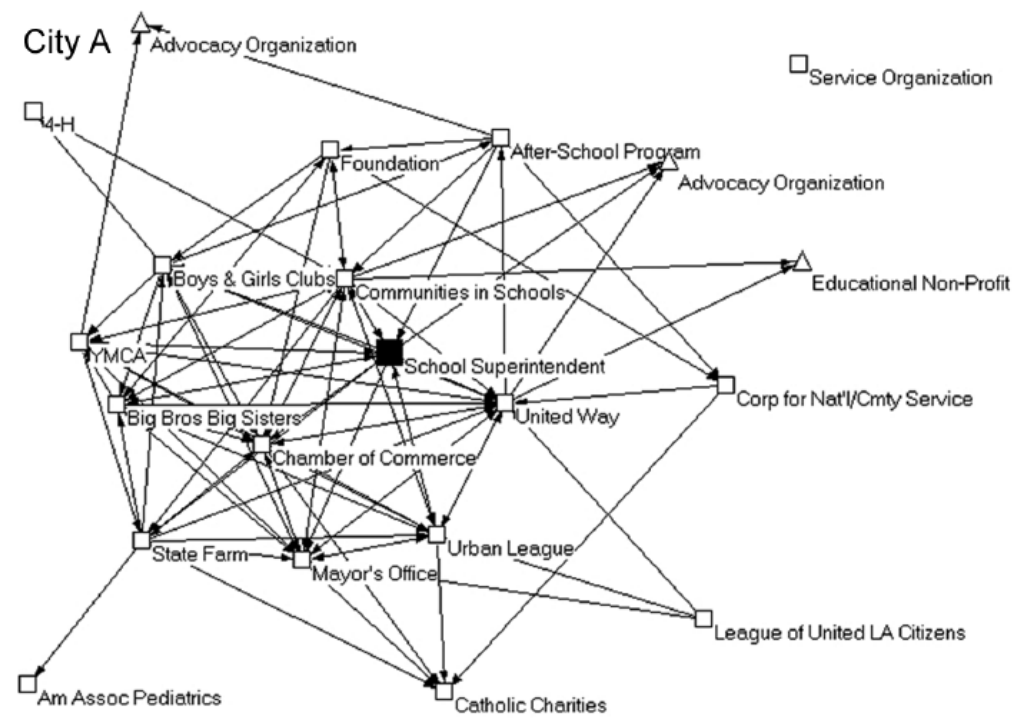

City B

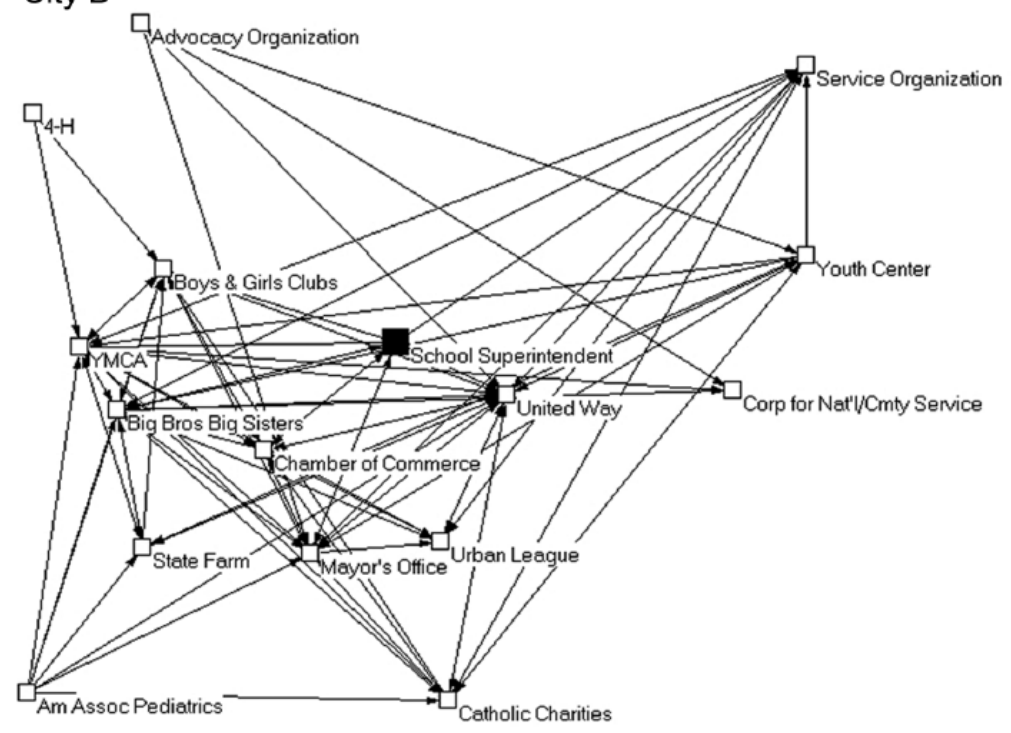

Figure 2. City A and City B's whole dropout prevention network structures. 
Network members in City A reported an average of 4.8 dropout prevention partners with whom they cooperated in one or more ways (Table 2). Information sharing was the most common way of cooperating with local partners (mean number of partners 3.8), followed by referring individuals (mean of 2.0 partners), joint service provision (mean 1.9), and resource sharing (1.7). A positive indication of collective dropout prevention capacity was the fact that only one member of City A's dropout prevention network was "disconnected," or not connected to any other members of the network (Scott, 2000).

City B network members reported an average of 6.7 dropout prevention partners (Table 2). As in City A, information sharing was the most common way organizations in City B reported cooperating with local partners for dropout prevention (mean number of partners 4.9), followed by referring individuals (2.9 partners), sharing resources ( 2.8 partners), and joint services (2.5). None of the City B dropout prevention networks was completely disconnected from other members (Scott, 2000).

City A's lower average numbers of cooperative ties may be partly explained by coalition meeting notes characterizing their region as "so big geographically it can be impossible to impact the whole city; [We] must choose neighborhoods or small slices of population to help." In contrast, City B's study participants noted their relatively small size as a communication advantage. As the American Academy of Pediatrics representative put it, "[W]e're fortunate to be a small enough community that a lot of people do know each other," and the head of a youth service organization noted that "we see each other every couple of weeks and we are meeting and then there's a lot of informal in between."

Despite the differing levels of dropout prevention across the two cities, interviews indicated generally consistent patterns of cooperative activities in each city for students from preschool through high school. The most common activities, cited by at least three respondents in each city, were after-school programs, one-to-one mentoring, and support for families-including child abuse prevention, postadoption services to strengthen family bonds, and education for teen parents.

\section{How Were School Systems Working With Local Partners to Improve High School Graduation Rates?}

Egocentric analyses revealed that City A superintendent's most multiplex ties were with Big Brothers Big Sisters and Communities in Schools (Figure 1). Both organizations provided services in public schools: Big Brothers Big 
Sisters ran mentoring programs in some schools and Communities in Schools offered intensive support services for children referred by school staff, including academic support, parental involvement, social services, and guidance. The next most multiplex relationship was with the United Way. This included reciprocal information exchange, referrals from the school system to the United Way, and joint programming, in addition to United Way funding of school initiatives.

City B superintendent's most multiplex ties were with the mayor's office, United Way, and Chamber of Commerce. The mayor's office was sufficiently involved in a truancy center to prompt improvements in attendance records. In their interview, the mayor's office representative also cited financial support to the school system, including funding for alternative high schools and an appropriation to pilot test an after-school program for at-risk middle schoolers, "to get this up and running so we wouldn't have to necessarily worry about that first check, for a funder to come in before we launch it." Many United Way-funded family resource centers were in schools. These were described as "one stop shopping for low-income families to get services and to be empowered to deal with problems they are facing in their community or school." The Chamber of Commerce provided local job growth information to the school district to inform career academy foci and also engaged a number of community partners to develop recommendations for the public school system on how to reduce the dropout rate. Neither city's school superintendent's office was directly connected to 4-H, Catholic Charities, or the American Academy of Pediatrics.

Almost half of the City A superintendent's ties with dropout prevention partners were reciprocal (45\%), versus $30 \%$ in City B. The City B superintendent's less reciprocal relationships may have reflected the school system's crisis at that time. In both cities, connections such as those to the YMCA, mayor's office, United Way, and Chamber of Commerce indicated that school systems had multisectoral ranges of dropout prevention ties.

Overall, egocentric analyses suggest that superintendent offices in both cities worked in a range of ways with dropout prevention partners across sectors. However, whole network analyses revealed that superintendents were generally not the most central players in local dropout prevention networks: The superintendent's office was the most central organization only for joint services in City B (Table 3). Representatives of both school systems described units that used community partners to address early warning signs of disengagement such as attendance problems. However, in City B, the heads of two community organizations noted severe constraints on the school system's ability to engage other supportive systems. As the family service agency CEO observed, 


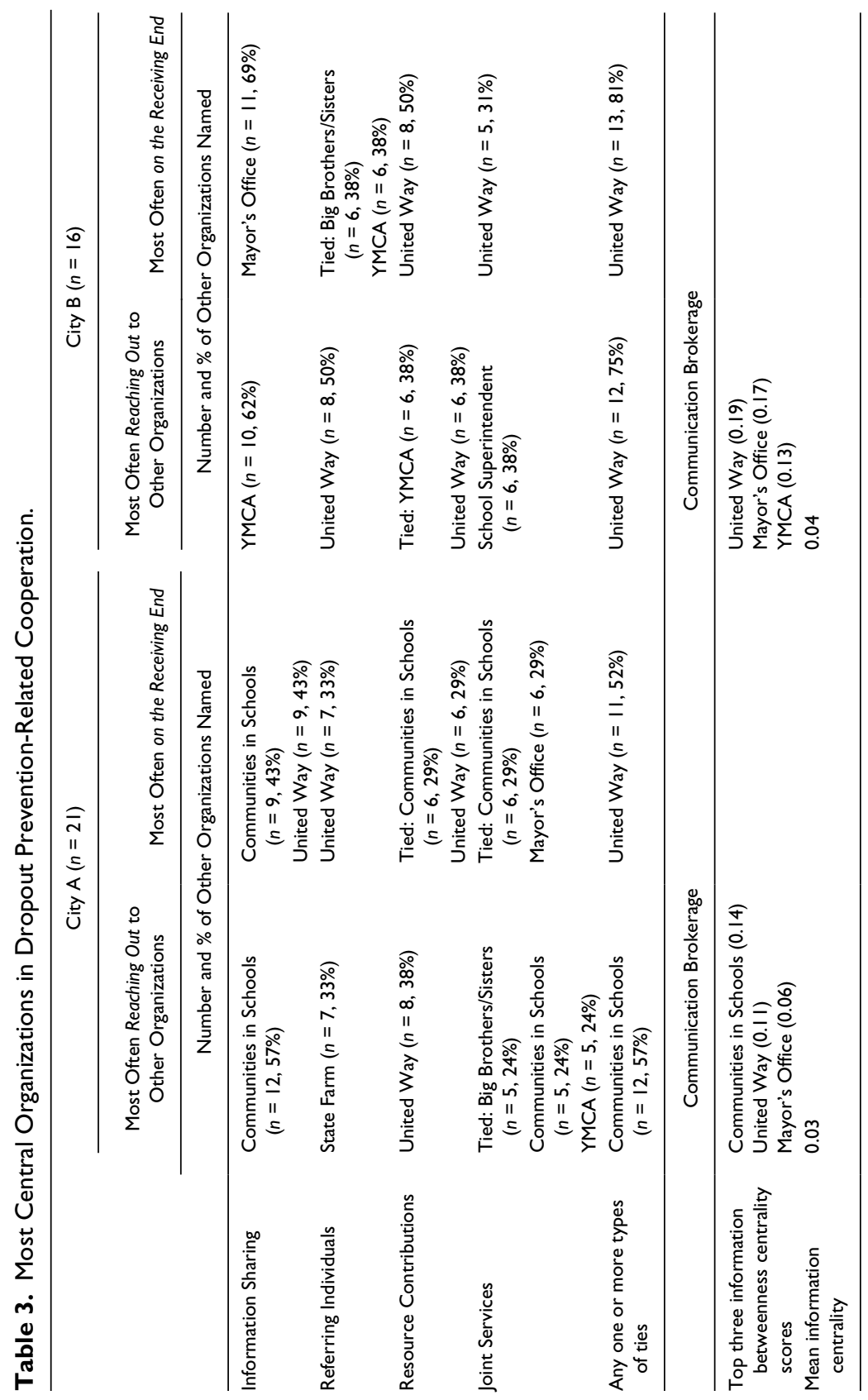


We've got a school district in chaos and that's really affected it big time . . . they've had turnover [in] superintendents. . . . Because schools haven't been at the table and it's still a little hard to talk about true effective dropout prevention when schools aren't engaged.

Perhaps in part because of this crisis, the CEO of Big Brothers Big Sisters noted that

still the school systems ... doesn't quite get it totally that they need to be including an organization like Big Brothers, Big Sisters, you know, the youth centered groups as part of the strategy ... we are an afterthought.

We did not find qualitative evidence explaining why the school system was not a central actor in City A's dropout prevention network.

\section{How Were Other Local Organizations Cooperating With Each Other to Improve High School Graduation Rates?}

In interviews, nonschool participants described both service and policyrelated information sharing. In City A, Big Brothers Big Sisters and Communities in Schools staff conferred informally at schools where both operated. The City A United Way hosted a collaborative for health and human services enabling agency leaders to meet face-to-face, including some such as 4-H, which the United Way was not funding. The mayor's office also sent a representative to meetings of that collaborative. Big Brothers Big Sisters and Boys and Girls Club both provided information to the Chamber of Commerce. Big Brothers Big Sisters shared information with LULAC for the Hispanic community. The Urban League, an advocacy organization representing African Americans, kept the mayor's office informed about issues of importance to their stakeholders.

Representatives from a wide range of organizations reported referring children and caregivers to other network members for mentoring, health and social services, and career preparation. In City A, the physician representing the American Academy of Pediatrics reported referring children to the YMCA and Big Brothers Big Sisters, which in turn referred children to Communities in Schools. Among other referrals, Communities in Schools connected high school students who had undergone their job training to the YMCA, which their representative described as "a wonderful training ground, particularly for teenagers but also young college students. And if they do well, basically they can start their careers there, put themselves through school and then move on through the system at the Y." The City B American Academy of 
Pediatrics member also referred patients to the YMCA and Big Brothers Big Sisters, as well as the Boys and Girls Club. In addition, she referred patients to Catholic Charities because both served refugees. Two youth service providers referred young people to each other for services either one did not provide. In both cities, the United Way received referrals, and in one city the United Way also referred children and families through its health and human services hotline.

Unsurprisingly given their reliance on workplace donations and their donors' stake in education, the United Way provided major funding for dropout prevention-related services in both cities. This included grants for Big Brothers Big Sisters, Boys and Girls Club, and Catholic Charities. State Farm sponsored several Urban League programs in one city and was encouraging Communities in Schools to apply for grants. One mayor's office reported funding the YMCA for dropout prevention programming. In-kind contributions included staff training provided by one youth service agency for another.

Joint services included Communities in Schools and Big Brothers Big Sisters staff working together with children at Boys and Girls Club sites; a Communities in Schools staff member working at a YMCA camp; a jointly financed Boys and Girls Club YMCA in public housing, which in turn referred children for Big Brothers Big Sisters mentoring at Boys and Girls Club sites; several agencies sharing space in an office complex, including Big Brothers Big Sisters and an agency providing crisis relief services; and 4-H and the Afterschool Alliance jointly providing a career awareness program for children in schools.

Table 3 lists the organizations reporting each type of tie with the greatest numbers of other local organizations. Communities in Schools reported the most outreach to other local organizations in City A, which indicated at least one dropout prevention activity with 12 of the 18 other local affiliates of national America's Promise Alliance partners. In addition, Communities in Schools had the highest information betweenness centrality score in City A, at 0.14 , compared with a mean of 0.03. Communities in Schools provided intensive social, academic, and other services to pre-K through high school children and youth throughout the City A metropolitan area, but was not present in City B.

The United Way was a central participant in both dropout prevention networks. Eleven of the 18 other organizations in City A cited the United Way as a dropout prevention partner, making it the most frequently named in the city. The United Way also had the second highest information betweenness centrality score in City A, at 0.11 ; this indicates potential to disseminate information about dropout prevention. Child and youth programming was the largest part of the City A United Way's funding portfolio, including character 
building, mentoring, and organized youth activities such as Boys and Girls Clubs, Big Brothers Big Sisters, Boy Scouts, and Girl Scouts.

In City B, the United Way reported having at least one dropout prevention tie with 12 of the 15 other local America's Promise affiliates, and 13 of the 15 reported one or more such ties with the United Way, also making it the most frequently named dropout prevention partner in this city. The United Way also had the highest information betweenness centrality score in City B, of 0.19 , relative to a sample mean of 0.04 . In City B, after the United Way, the organizations with the highest dropout prevention-related information centrality were the mayor's office (information centrality score $=0.17$ ) and the YMCA (0.13). Staff at the mayor's office facilitated interorganizational cooperation on dropout prevention.

Although the United Way, which mediates between business and human services, was central in both cities' networks, business sector entities such as the Chamber of Commerce were not (Table 3). In both cities, dropout prevention meetings of Featured Communities affiliates included discussion of how to increase involvement by business. Businesses constituted a distinct minority of both dropout prevention networks (Table 2) as well as participants in the one educational summit from which we secured attendance records, that is, $13 \%$. Participants in that summit also noted the need to recruit more businesses. Yet a summit breakout session one of the authors attended included discussion of schools as insular and isolated from best practices because of lack of funding. Interviews and meeting minutes also indicate that community organization leaders thought of businesses largely in terms of financial support (e.g., "corporate investment to increase impact of programs"), whereas business leaders were more likely to frame their contributions in terms of information sharing (e.g., high school graduation and job market trends) and supporting better school performance (e.g., through teacher training).

\section{Discussion}

Social network analyses of these two cities reveal how school systems cooperated in a combination of ways with partners across nonprofit, government, and business sectors. Nonetheless, given schools' central role in children's education, it was striking that superintendents' offices were generally not central in local dropout prevention networks. At first glance, one might think that schools should form more direct relationships with community organizations. However, the current study suggests more efficient possibilities.

Given how many competing demands school systems face, one strategic way to enhance their dropout prevention networks may be to use key brokers 
to build and leverage relationships with a range of local organizations (Bennett \& Thompson, 2011). At the service delivery level, results of the current study suggest that the YMCA and Communities in Schools may be particularly valuable partners. The YMCA, which was prominent in both cities' dropout prevention networks, has long promoted family and community health through a wide range of programs in communities throughout the United States. Communities in Schools is not as ubiquitous as the Y, but it was central in the one city in which it was present. Communities in Schools coordinators based in public schools throughout 27 states connect students to community resources tailored to individual needs (Communities in Schools, 2013). Because these community organizations provide direct services and connect individual children to other community resources, they may have a particularly realistic appreciation of how to build more supportive systems for children and their families from the ground up. In addition, Communities in Schools staff discussed programs with the United Way and Chamber of Commerce as well as co-chaired an advocacy group with a children's advocacy organization. Communities in Schools may therefore be uniquely well positioned to inform dropout prevention initiatives about interdependencies of child development; family needs; educational, health and human service capacity; the local economy; and business sector priorities.

At the policy level, mayors may also be powerful allies in dropout prevention. Perhaps motivated in part because of the links between unaddressed youth needs and violent crime (PR Newswire, 2007), a high voter priority, mayors can raise the public profile of dropout prevention. In the current study, the mayor in one city also provided crucial start-up funding for a dropout prevention initiative. Mayors may also encourage public support for taxes especially critical to supporting schools in weak economic contexts (Bennett \& Thompson, 2011; Johansson, 2010).

Finally, as a workplace-based giving program, the United Way may help schools connect with a broader range of both health and human services and business partners. In 2008, the United Way began a national 10-year initiative to cut the high school dropout rate in half. Superintendents in both cities studied had multiplex and reciprocal relationships with the United Way, and the United Way was among the most central organizations in both networks. By continually scanning local population needs, encouraging joint programs among funding recipients (Provan, Beyer, \& Kruytbosch, 1980), and providing community forums and referral hotlines, United Ways are well positioned to advise school systems on how to connect children and youth with a range of supportive services.

The relatively low proportion of network members from business and the different emphases on how businesses should support higher graduation rates 
suggest both relatively few ties between schools and the business sector and asymmetrical expectations (Boyles, 2005). Based on its centrality in both cities' dropout prevention networks and mission as an intermediary between employers and community agencies, the United Way may be well positioned to increase business investment in this cause. This in turn may help activate a sector with a tremendous stake in dropout prevention as well as a range of resources to deploy toward this goal. Community leaders may have greater success engaging business if they approach them as partners in information exchange and accountability as well as money, a dialog the United Way might broker. Previous research suggests that partnerships between schools and business can improve youth academic performance as well as supportive factors such as motivation and healthy behavior (Scales et al., 2005).

Given this study's reliance on a single representative of each organization, the absence of reported connections between school superintendents in both cities with 4-H, Catholic Charities, and the American Academy of Pediatrics does not necessarily mean that there was no such cooperation. However, the fact that none of the study's knowledgeable representatives was aware of any such connections does imply that these were not prominent relationships. Interviews suggest cooperation between these organizations and individual schools, including 4-H enrichment programs at schools, Catholic Charities funding of English classes for immigrants at public schools, and provision of pre- and postnatal services by a local clinic at area high schools. Findings from the current study suggest there may be opportunities for school systems to tap these organizations for community-level initiatives as well. In City B, the superintendent's office was central in joint services overall, demonstrating substantial commitment to this highly interdependent level of dropout prevention cooperation.

Several limitations restrict inferences from this study. First, the study team chose the two cities examined here based on their receipt of dropout prevention grants and having high response rates to the initial online survey. Findings from this study may thus best apply to other cities with a preexisting shared commitment to dropout prevention. Although the network sampling strategy included additional organizations nominated by two or more local affiliates of America's Promise Alliance, they were intended as illustrative samples rather than exhaustive representations of dropout prevention activity in either city. It is unlikely that all study participants were aware of all dropout prevention-related ties between their organizations and all other organizations within their cities. Thus, the number of ties is likely underrepresented here. However, prior research on interorganizational ties has sometimes used key informants on the basis that agency administrators could speak knowledgeably to whether or not their agencies 
had such ties with other agencies such as information, referrals, and joint programs (Boje \& Whetten, 1981; Bolland \& Wilson, 1994; Isett, 2005). In addition, participants were high-level administrators chosen for their knowledge of youth-related programming. Hence, we have confidence in the validity of the ties participants reported. Finally, collecting data at only one point in time yielded a static depiction of inherently dynamic patterns of community activity, although research has found health and human service networks to be relatively stable even during attempts to spur increased connection (Isett, 2005). However, given that no previous research has systematically measured dropout prevention networks, we believe that this article's combined quantification of ties and qualitative characterization contribute to the literature on community-based efforts to improve outcomes for children and youth.

After 40 years, the high school dropout rate remains stubbornly high. Twenty years ago, the National Research Council Panel on High-Risk Youth (1993) noted that

the primary institutions that serve youth —-health, schools, employment, trainingare crucial, and we must begin with helping them respond more effectively to contemporary adolescent needs. Effective responses will involve pushing the boundaries of these systems, encouraging collaborations between them and reducing the number of adolescents whose specialized problems cannot be met through primary institutions.

By broadening the perspective on potential solutions to the community, this study may offer some potential insights into how to support more youth through high school graduation. School district offices have a vital role to play in engaging community partners toward this end because they have staff who already work with other organizations, whose leaders in turn may also prefer a single point of contact who has the authority to approve new initiatives. However, even school district staff must be highly selective in how they invest their time. Perhaps the solution does not lie in asking schools to maintain yet more direct connections with the myriad local organizations also affecting children. Instead, educators might use a network perspective to identify how partners can build community capacity to support children. Similarly, external entities might help schools improve graduation rates more effectively by helping them identify and build strong ties with key partners than through broad encouragements to collaborate. We hope these findings demonstrate the utility of systematically examining dropout prevention as networks of activities with current and potential partners who can collectively provide the support children need to thrive. 


\section{Declaration of Conflicting Interests}

The authors declared no potential conflicts of interest with respect to the research, authorship, and/or publication of this article.

\section{Funding}

The authors disclosed receipt of the following financial support for the research, authorship, and/or publication of this article: Elizabeth Gifford, Ashley Corra, and Yu Bai had time paid for collecting and analyzing the data as part of an evaluation contract with the America's Promise Alliance. Rebecca Wells served as a paid research consultant to design data collection.

\section{References}

Abar, B., Abar, C., Lippold, M., Powers, C. J., \& Manning, A. E. (2012). Associations between reasons to attend and late-high school dropout. Learning and Individual Differences, 22, 856-861.

Adelman, H. S., \& Taylor, L. (1997). Addressing barriers to learning: Beyond school-linked services and full-service schools. American Journal of Orthopsychiatry, 67, 408-421.

Agranoff, R. (1991). Human services integration: Past and present challenges in public administration. Public Administration Review, 51, 533-542.

Anderson, B. S., Butts, C., \& Carley, K. (1999). The interaction of size and density with graph-level indices. Social Networks, 21, 239-268.

Bennett, J. V., \& Thompson, H. C. (2011). Changing district priorities for schoolbusiness collaboration superintendent agency and capacity for institutionalization. Educational Administration Quarterly, 47, 826-868.

Boje, D. M., \& Whetten, D. A. (1981). Effects of organizational strategies and contextual constraints on centrality and attributions of influence in interorganizational networks. Administrative Science Quarterly, 26, 378-395.

Bolland, J. M., \& Wilson, J. V. (1994). Three faces of integrative coordination: A model of interorganizational relations in community-based health and human services. Health Services Research, 29, 341-366.

Borgatti, S. P., \& Ofern, B. (2010). Overview: Social network theory and analysis. In A. J. Daly (Ed.), Social network theory and educational change (pp. 17-30). Cambridge MA: Harvard Education Press.

Bowers, A. J., Sprott, R., \& Taff, S. A. (2013). Do we know who will drop out? A review of the predictors of dropping out of high school: Precision, sensitivity, and specificity. High School Journal, 96, 77-100.

Boyles, D. R. (2005). The exploiting business: School-business partnerships, commercialization, and students as critically transitive citizens. In D. R. Boyles (Ed.), Schools or markets: Commercialism, privatization, and school-business partnerships (pp. 217-240). Philadelphia, PA: Psychology Press.

Brown, E. C., Hawkins, J. D., Arthur, M. W., Briney, J. S., \& Fagan, A. (2011). Prevention service system transformation using Communities That Care. Journal of Community Psychology, 39, 183-201. doi:10.1002/jcop.20426 
Burt, R. S. (1992). Structural holes: The social structure of competition. Cambridge, MA: Harvard University Press.

Burt, R. S. (2004). Structural holes and good ideas. American Journal of Sociology, 110, 349-399.

Coburn, C. E., \& Russell, J. L. (2008). District policy and teachers' social networks. Educational Evaluation and Policy Analysis, 30, 203-235. doi:10.3102/ 0162373708321829

Coleman, J. S. (1988). Social capital in the creation of human capital. American Journal of Sociology, 94(Suppl.), s95-s120.

Communities in Schools. (2013). Who we are. Retrieved from http://www.communitiesinschools.org/about/

Cook, K. S., Emerson, R. M., \& Gillmore, M. R. (1983). The distribution of power in exchange networks: Theory and experimental results. American Journal of Sociology, 89, 275-305.

Daly, A. J., \& Finnigan, K. S. (2010). A bridge between worlds: Understanding network structure to understand change strategy. Journal of Educational Change, 11, 111-138.

Davis, L. E., Ajzen, I., Saunders, J., \& Williams, T. (2002). The decision of African American students to complete high school: An application of the theory of planned behavior. Journal of Educational Psychology, 94, 810-819.

de Nooy, W., Mrvar, A., \& Batagelj, V. (2005). Exploratory social network analysis with Pajek. New York, NY: Cambridge University Press.

Dynarski, M., \& Gleason, P. (2002). How can we help? What we have learned from recent federal dropout prevention evaluations. Journal of Education for Students Placed at Risk, 7, 43-69.

Fairnington, A. (2004). Communities that care: A case study of regeneration from Wales. Critical Public Health, 14, 27-36.

Farahati, F., Marcotte, D. E., \& Wilcox-Gök, V. (2003). The effects of parents' psychiatric disorders on children's high school dropout. Economics of Education Review, 22, 167-178. doi:10.1016/s0272-7757(02)00031-6

Foster-Fishman, P. G., Salem, D. A., Allen, N. A., \& Fahrbach, K. (2001). Facilitating interorganizational collaboration: The contributions of interorganizational alliances. American Journal of Community Psychology, 29, 875-905.

Freeman, L. C., Roeder, D., \& Mulholland, R. (1979). Centrality in social networks: Experimental results. Social Networks, 2, 119-141.

Freudenberg, N., \& Ruglis, J. (2007). Reframing school dropout as a public health issue. Preventing Chronic Disease, 4(4), 1-11.

Friedkin, N. E., \& Slater, M. R. (1994). School leadership and performance: A social network approach. Sociology of Education, 67, 139-157.

Goldring, E., \& Sims, P. (2005). Modeling creative and courageous school leadership through district-community-university partnerships. Educational Policy, 19, 223-249.

Granovetter, M. S. (1973). The strength of weak ties. American Journal of Science, $78,1360-1380$. 
Hammond, C., Linton, D., Smink, J., \& Drew, S. (2007). Dropout risk factors and exemplary programs. Clemson, SC: National Dropout Prevention Center, Communities in Schools.

Hasenfeld, Y. (1972). People processing organizations: An exchange approach. American Sociological Review, 37, 256-263.

Hirota, J. M. (2005). Reframing education: The partnership strategy and public schools (A report to Carnegie Corporation of New York). New York, NY: Chapin Hall Center for Children.

Hirschfield, P. (2009). Another way out: The impact of juvenile arrests on high school dropout. Sociology of Education, 82, 368-393.

Hite, J. M., Williams, E. J., \& Baugh, S. C. (2005). Multiple networks of public school administrators: An analysis of network content and structure. International Journal on Leadership in Education, 8, 91-122.

Isett, K. R. (2005). The evolution of dyadic interorganizational relationships in a network of publicly funded nonprofit agencies. Journal of Public Administration Research and Theory, 15, 149-165.

Johansson, O. (2010). From entrepreneurialism to social regulation: Nashville's business elite and local education. Southeastern Geographer, 50, 39-57.

Kahne, J., Brown, A., \& Quinn, T. (2001). Leveraging social capital and school improvement: The case of a school network and a comprehensive community initiative in Chicago. Educational Administration Quarterly, 37, 429-461.

Knoke, D., \& Yang, S. (2007). Social network analysis (Vol. 154). Thousand Oaks, CA: Sage.

Laumann, E. O., Marsden, P. V., \& Prensky, D. (1992). The boundary specification problem in network analysis. In L. C. Freeman, D. R. White, \& A. K. Romney (Eds.), Research methods in social network analysis (pp. 61-87). New Brunswick, NJ: Transaction.

Lawson, H. A., Claiborne, N., Hardiman, E., Austin, S., \& Surko, M. (2007). Deriving theories of change from successful community development partnerships for youths: Implications for school improvement. American Journal of Education, 114, 1-40.

Lehr, C. A., Hansen, A., Sinclair, M. F., \& Christenson, S. L. (2003). Moving beyond dropout towards school completion: An integrative review of data-based interventions. School Psychology Review, 32, 342-364.

Levine, S., \& White, P. E. (1961). Exchange as a conceptual framework for the study of interorganizational relationships. Administrative Science Quarterly, 5, 583-601.

Lin, N., Cook, K. S., \& Burt, R. S. (2001). Social capital: Theory and research. New York, NY: Aldine de Gruyter.

Maton, K. I. (2008). Empowering community settings: Agents of individual development, community betterment, and positive social change. American Journal of Community Psychology, 41, 4-21.

Matthews, C. (2012). National graduation rate keeps climbing; 1.1 million students still fail to earn diplomas (Diplomas Count). Bethesda, MD: EPE Research Center. 
Mediratta, K. (2007). Outside in: Communities in action for education reform. Theory Into Practice, 46, 194-204.

Melchior, A., \& Bailis, L. N. (2002). Impact of service-learning on civic attitudes and behaviors of middle and high school youth: Findings from three national evaluations. Advances in Service-Learning Research, 1, 201-222.

Miles, M. B., \& Huberman, A. M. (1994). Qualitative data analysis: An expanded sourcebook (2nd ed.). Thousand Oaks, CA: Sage.

Miller, P. M. (2009). Boundary spanning in homeless children's education notes from an emergent faculty role in Pittsburgh. Educational Administration Quarterly, 45, 616-630.

National Research Council Panel on High-Risk Youth. (1993). Losing generations: Adolescents in high-risk settings. Washington, DC: National Academies Press.

Newell, J., \& Akers, C. (2010). The mobile story: Data-driven community efforts to raise graduation rates. New Directions for Youth Development, 2010(127), 111-121.

Peurach, D. J., \& Glazer, J. L. (2012). Reconsidering replication: New perspectives on large-scale school improvement. Journal of Educational Change, 13, 155-190.

PR Newswire. (2007, March 22). Mayors' 2007 10-point plan: Mayors, police chiefs and education leaders hold national summit on at-risk youth, gang violence, high school dropouts; mayors call for stronger partnerships to help at-risk youth. Retrieved from http://www.prnewswire.com/news-releases/mayors2007-10-point-plan-mayors-police-chiefs-and-education-leaders-hold-nationalsummit-on-at-risk-youth-gang-violence-high-school-dropouts-51612717.html

Provan, K. G., Beyer, J. M., \& Kruytbosch, C. (1980). Environmental linkages and power in resource-dependence relations between organizations. Administrative Science Quarterly, 25, 200-225.

Provan, K. G., \& Huang, K. (2012). Resource tangibility and the evolution of a publicly funded Health and Human Services network. Public Administration Review, 72, 366-375.

Provan, K. G., \& Milward, H. B. (1995). A preliminary theory of interorganizational network effectiveness: A comparative study of four community mental health systems. Administrative Science Quarterly, 40, 1-33.

Randolph, K. A., \& Johnson, J. L. (2008). School-based mentoring programs: A review of the research. Children \& Schools, 30, 177-185.

Ritter, G. W., Barnett, J. H., Denny, G. S., \& Albin, G. R. (2009). The effectiveness of volunteer tutoring programs for elementary and middle school students: A metaanalysis. Review of Educational Research, 79, 3-38.

Rouse, C. E. (2005). The labor market consequences of an inadequate education. Retrieved from http://devweb.tc.columbia.edu/manager/symposium/Files/77 Rouse paper.pdf

Rouse, C. E., \& Kemple, J. (2009). America's high schools: Introducing the issue. Future of Children, 19, 3-15.

Rumberger, R. W. (2011). Dropping out: Why students drop out of high school and what can be done about it. Cambridge MA: Harvard University Press.

Rumberger, R. W., \& Larson, K. A. (1998). Student mobility and the increased risk of high school dropout. American Journal of Education, 107, 1-35. 
Ryan, J. P., Marsh, J. C., Testa, M. F., \& Louderman, R. (2006). Integrating substance abuse treatment and child welfare services: Findings from the Illinois alcohol and other drug abuse waiver demonstration. Social Work Research, 30, 95-107.

Scales, P. C., Blyth, D. A., Berkas, T. H., \& Kielsmeier, J. C. (2000). The effects of service-learning on middle school students' social responsibility and academic success. Journal of Early Adolescence, 20, 332-358.

Scales, P. C., Foster, K. C., Mannes, M., Horst, M. A., Pinto, K. C., \& Rutherford, A. (2005). School-business partnerships, developmental assets, and positive outcomes among urban high school students: A mixed-methods study. Urban Education, 40, 144-189.

Scott, J. (2000). Social network analysis (2nd ed.). Thousand Oaks, CA: Sage.

Smith, A. K., \& Wohlstetter, P. (2001). Reform through school networks: A new kind of authority and accountability. Educational Policy, 15, 499-519.

Smith, J., \& Wohlstetter, P. (2006). Understanding the different faces of partnering: A typology of public-private partnerships. School Leadership \& Management, 26, 249-268.

Song, M., \& Miskel, C.G. (2005). Who are the influentials? A cross-state social network analysis of the reading policy domain. Educational Administration Quarterly, 41, 7-48.

Sum, A., IKhatiwada, I, McLaughlin, J., \& Palma, S. (2009). The consequences of dropping out of high school: Joblessness and jailing for high school dropouts and the high cost for taxpayers (Paper 23). Boston, MA: Center for Labor Market Studies, Northeastern University.

Swanson, C. B. (2009). Closing the graduation gap: Educational and economic conditions in America's largest cities. Cities in Crisis, 5-22.

Tyler, J. H., \& Lofstrom, M. (2009). Finishing high school: Alternative pathways and dropout recovery. Future of Children, 19, 77-103.

U.S. Census Bureau. (2010). American FactFinder. Retrieved from http://factfinder2. census.gov

Wasserman, S., \& Faust, K. (1994). Social network analysis: Methods and applications. New York, NY: Cambridge University Press.

Wohlstetter, P., \& Smith, J. (2006). Improving schools through partnerships: Learning from charter schools. Phi Delta Kappan, 87, 464-467.

Yin, R. K. (2009). Case study research: Design and methods. Thousand Oaks, CA: Sage.

\section{Author Biographies}

Rebecca Wells is a professor in the Department of Health Policy and Management at Texas A\&M. Her work focuses on cooperation within and across health and human service organizations.

Elizabeth Gifford is a research scientist at the Center for Child \& Family Policy at Duke University. Her primary research interests involve evaluating programs and policies that are designed to improve health outcomes for vulnerable children. 
Yu Bai is a statistician at the Center for Child \& Family Policy at Duke University. $\mathrm{He}$ is working with his colleagues on two projects, America's Promise Alliance and the Child and Family Support Teams Initiative.

Ashley Corra is a research analyst at the Center for Child \& Family Policy at Duke University. She received her undergraduate degree from the University of North Carolina at Chapel Hill and a master's degree in clinical psychology from Loyola University Maryland. 